Department of Philosophy Georgetown University

Spring Semester 2001

Wednesdays, 10:15-12:45
Instructor: LeRoy Walters

Office Telephone: 202-687-7174

Office Hours: Tuesdays, 1:45-3:15, or by Appointment

E-mail Address: walters1@gunet.georgetown.edu

\title{
ETHICS AND HUMAN GENETICS
}

PHIL 454-01 and 554-01

The primary goal of this course is to examine the ethical dimensions of human genetics. In the first part of the course we will begin by reading a recent popular overview of human genetics. Next, we will review how genetic knowledge was misused in coercive eugenics programs undertaken in two countries - the United States and Germany - during the first half of the twentieth century.

In the central section of the course we will explore three major topics: the Human Genome Project, genetic testing and screening, and gene therapy and germ-line genetic modification. For each of these topics we will attempt to learn something of the history of, and the social context for, the activity, then explore the ethical and public-policy questions that are raised by the activity.

In the final part of the course three additional topics will be considered: genetic enhancement, behavioral genetics, and racial research. The ethical implications of these three topics will be explored, as well as their implications for our understanding of the human person.

We will conclude by asking ourselves, aided by two social scientists, whether genes have in fact become cultural icons.

\section{OVERVIEW}

Class 1 (January 17): Introduction to the Course

Class 2 (January 24): Genome I

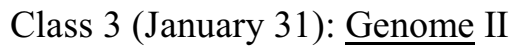

Class 4 (February 7): Eugenics I

Class 5 (February 14): Eugenics II

Class 6 (February 21): The Human Genome Project

Class 7 (February 28): Genetic Testing and Screening I 
Spring Break

Class 8 (March 14): Genetic Testing and Screening II

Class 9 (March 21): Gene Therapy and Germ-Line Genetic Modification

Class 10 (March 28): Genetic Enhancement

Class 11 (April 4): Behavioral Genetics I

Class 12 (April 11): Behavioral Genetics II

Class 13 (April 18): Racial Research I

Class 14 (April 25): Racial Research II

Class 15 (May 2): Retrospect and Prospect: The Gene as a Cultural Icon

\section{TEXTBOOKS}

William R. Clark and Michael Grunstein, Are We Hardwired? The Role of Genes in Human Behavior (New York: Oxford University Press, 2000). Cited as Clark-Grunstein, Hardwired.

Mark S. Frankel and Audrey R. Chapman, eds., Human Inheritable Genetic Modifications: Assessing Scientific, Ethical, Religious, and Policy Issues (Washington, DC: American Association for the Advancement of Science, 2000). Cited as Frankel-Chapman, HIGM. See http://www.aaas.org/spp/dspp/sfrl/germline/report.pdf

Daniel J. Kevles, In the Name of Eugenics (Berkeley: University of California Press, 1986) (reprinted in 1995 by Harvard University Press). Cited as Kevles, Eugenics.

Philip Kitcher, The Lives to Come (New York: Simon \& Schuster, 1996 [1997]). Cited as Kitcher, Lives.

Dorothy Nelkin and M. Susan Lindee, The DNA Mystique: The Gene as a Cultural Icon (New York: W. H. Freeman, 1995 [1996]). Cited as Nelkin-Lindee, Mystique.

Matt Ridley, Genome: The Autobiography of a Species in 23 Chapters (New York: HarperCollins, 1999 [2000]). Cited as Ridley, Genome.

William H. Tucker, The Science and Politics of Racial Research (Urbana, IL: University of Illinois Press, 1994. Cited as Tucker, SPRR. 


\section{READINGS}

Class 2 (January 24): Genome I

Ridley, Genome, Preface and pp. 1-146 and endnotes.

Class 3 (January 31): Genome II

Ridley, Genome, pp. 147-313 and endnotes.

Class 4 (February 7): Eugenics I

Kevles, Eugenics, both prefaces and Chapters I-X and endnotes.

*United States Supreme Court, Buck v. Bell (1927); reprinted in Tom L. Beauchamp and LeRoy Walters, eds., Contemporary Issues in Bioethics, 5th ed. (Belmont, CA:

International Thompson Publishing, 1999), pp. 526-527. Hereafter cited as BeauchampWalters, $\underline{\text { CIB55. }}$

*Stephen Jay Gould, "Carrie Buck's Daughter," from The Flamingo's Smile (New York: W.W. Norton, 1985); reprinted in Beauchamp-Walters, CIB5, pp. 528-532.

+ Critique of Buck v. Bell due.

Class 5 (February 14): Eugenics II

Kevles, Eugenics, Chapters XI-XIX and endnotes.

Kitcher, Lives, Chapter 8 and endnotes.

*Robert Jay Lifton, "Sterilization and the Nazi Biomedical Vision," from The Nazi Doctors (New York: Basic Books, 1986); reprinted in Beauchamp-Walters, CIB5, pp. 533-540.

Video: The Lynchburg Story.

Class 6 (February 21): The Human Genome Project

Kitcher, Lives, Chapter 4.

*James D. Watson, "Genes and Politics" [excerpts], Journal of Molecular Medicine 75 (9): 624-636; September 1997; reprinted in Beauchamp-Walters, CIB5, pp. 550-555.

* Materials available on reserve or distributed in class 
*Francis Collins, et al., "New Goals for the U.S. Human Genome Project: 1998-2003," Science 282 (5389): 682-689; October 23, 1998.

*Elizabeth Pennisi, "Finally, the Book of Life and Instructions for Navigating It," Science 288 (5475): 2304-2307; June 30, 2000.

Class 7 (February 28): Genetic Testing and Screening I

Kitcher, Lives, Chapters 1, 3, 6-7 and endnotes.

American Society of Human Genetics, Board of Directors, "Eugenics and the Misuse of Genetic Information to Restrict Reproductive Freedom," October 1998. Available on the World Wide Web at http://www.faseb.org/genetics/ashg/policy/pol-30.htm.

Spring Break

Class 8 (March 14): Genetic Testing and Screening II

*Institute of Medicine, Committee on Assessing Genetic Risks, Assessing Genetic Risks (excerpts); reprinted in Beauchamp-Walters, CIB5, pp. 559-567.

*E. Virginia Laphan, Chahira Kozma, and Joan O. Weiss, "Genetic Discrimination: Perspectives of Consumers," Science 274 (5287): 621-624; October 25, 1996; reprinted in Beauchamp-Walters, CIB5, pp. 568-573.

Kitcher, Lives, Chapters 9-10 and endnotes, 13-14 and endnotes.

+Please locate a recent state or federal bill, law, or executive order that deals with genetic testing or screening, bring a copy of the document to class, and be prepared to describe it.

Class 9 (March 21): Gene Therapy and Germ-Line Genetic Intervention

Kitcher, Lives, Chapter 5 and endnotes.

*W. French Anderson, "Human Gene Therapy" [excerpts], Nature 392 (Supplement, April 30, 1998),25-30; reprinted in Beauchamp-Walters, $\underline{\text { CIB5 }, ~ p p . ~ 580-586 . ~}$

*LeRoy Walters, "Bioethics and the Public Oversight of Human Gene Transfer Research," lecture given at the American Society for Bioethics and the Humanities Annual Meeting, Salt Lake City, UT, October 27, 2000.

Frankel-Chapman, HIGM, entire work. Available on the World Wide Web at http://www.aaas.org/spp/dspp/sfrl/germline/report.pdf.

+Short paper due. 
Class 10 (March 28): Genetic Enhancement

*LeRoy Walters and Julie Gage Palmer, The Ethics of Human Gene Therapy (New York: Oxford University Press, 1997), pp. 99-142.

*Jonathan Glover, What Sort of People Should There Be? (New York: Penguin Books, 1984), excerpts; reprinted in Beauchamp-Walters, CIB5, pp. 586-596.

*Erik Parens, "The Goodness of Fragility: On the Prospect of Genetic Technologies Aimed at the Enhancement of Human Capabilities," Kennedy Institute of Ethics Journal 5(2): 141-153; June 1995; reprinted in Beauchamp-Walters, CIB5, pp. 596-602.

Class 11 (April 4): Behavioral Genetics I

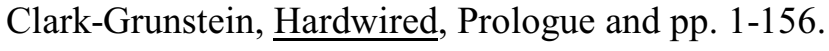

*Erik Parens, "Taking Behavioral Genetics Seriously," Hastings Center Report 26(4): 1318; July-August 1996.

Class 12 (April 11): Behavioral Genetics II

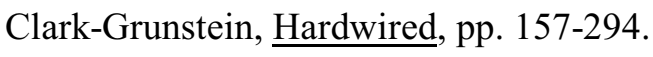

Kitcher, Lives, Chapters 11-12.

Class 13 (April 18): Racial Research I

Tucker, $\underline{\text { SPRR, }}$ Preface, Introduction, and Chapters 1-3 (including endnotes).

*William Shockley, "Ten Point Position Statement on Human Quality Problems [1968]," in Roger Pearson, ed., William Shockley on Eugenics and Race (Washington, DC: ScottTownsend Publishers, 1992), pp. 124-126.

Class 14 (April 25): Racial Research II

Tucker, $\underline{\text { SPRR}}$, Chapters 4-5 and Conclusion (including endnotes).

+Please find one example of supposedly-scientific racist literature on the World Wide Web, make enough copies for your classmates, and bring the copies to class for distribution.

Class 15 (May 2): Retrospect and Prospect: The Gene as a Cultural Icon

Nelkin-Lindee, $\underline{\text { Mystique, }}$ entire book, including Preface and endnotes. 


\section{REQUIREMENTS}

Students are requested to complete all assigned readings in advance of the class for which they are assigned and to participate actively in class discussion. The quality of the discussion will be heavily dependent on your knowledge and critical evaluation of the readings. This facet of each student's work will constitute $20 \%$ of the semester grade.

The one oral assignment in the course is to introduce an article or a chapter of a book to the class at the beginning of one class session during the semester. The introduction should summarize the reading very quickly and should be devoted primarily to a critical analysis of the reading. The introduction will be timed and should not exceed 10 minutes. This assignment will constitute $10 \%$ of each student's the final grade.

There will be three written assignments for the course. The first written assignment is a brief (2-4 double-spaced pages) critique of the United States Supreme Court decision in Buck v. Bell. This assignment should be handed in on Wednesday, February 7 . It will constitute $10 \%$ of the final grade.

The second written assignment is a short paper that critiques one of the assigned readings or another book or article chosen by the student in consultation with the instructor. The paper should not exceed ten (graduate students enrolling at the 546 level, twenty) double-spaced typed pages (font size 10 or higher!) and should reflect your ability to analyze critically the data and argumentation presented by the author(s) of the book or article. The critical essay is due on Wednesday, March 21. The grade on this essay will constitute $25 \%$ of the semester grade.

The second written assignment is a semester-end term paper on a topic of your choice related to ethics and human genetics. Criteria for evaluation of the term paper will be distributed later in the semester. In writing the term paper, please put yourself in the frame of mind of an author writing an article for publication in a philosophy or bioethics journal. If you succeed in this aim, you may find that you will indeed submit the paper for publication. The term paper should not exceed 2025 (graduate students, 30-35) double-spaced pages and should be documented in a standard, consistent style (for example, Turabian or the Chicago Manual of Style). The term paper is due one week after our final class meeting, on Wednesday, May 9. The grade on the final paper will constitute $35 \%$ of the semester grade.

Students are requested to submit the three written assignments on time, both in the interest of fairness (equal time for all students) and in the interest of efficiency (the instructor's opportunity to grade all papers within a particular time period). A personal or familial emergency can, of course, constitute a legitimate reason for an extension beyond a deadline, if an arrangement for such an extension is made before the deadline date. 